\title{
偏心圧縮力を受ける SRC 長柱の耐力 \\ STRENGTH OF A COMPOSITE LONG COLUMN SUBJECTED TO ECCENTRIC AXIAL FORCE
}

\author{
柴田道生*
}

Michio SHIBATA

\begin{abstract}
Theoretical and experimental studies are presented on the compressive strength of a composite long column. In the analysis, the critical conditions for the maximum load are given explicitly and general solutions of strength of composite long columns with arbitrary cross sections and constitutive relations are obtained. The governing equations are given in an analytical form for elastic perfectly-plastic composite columns, and obtained numerically for arbitrary constitutive relations. In the experimental study, total 12 specimens with 4 types of slenderness are tested for concentric and eccentric loading. Buildup wide-flange $\mathrm{H}-62 \times 60 \times 6 \times 6$ and $9 \phi$ reinforcing bars are encased in $12 \mathrm{~cm} \times 12 \mathrm{~cm}$ concrete cross section. Computed results show good agreements with exact numerical solutions and experiments.
\end{abstract}

Keywords : composite column, eccentric loading, maximum strength, critical condition, experiments

合成長柱, 偏心圧縮, 最大耐力, 停留条件, 座屈実験

\section{1 序}

合成構造梁一柱（beam-column）の耐力を求める手法は数多く提案 されているが, その多くは, 荷重または変形を徐々に増大させなが ら耐力が最大となる点を求めるという手法を取るので, 大量の数値 計算を必要とする ${ }^{1-5)}$. また, 解析ではコンクリートの劣化性状を正 確に考慮することができないので, 解析結果の検証では実験值との 比較検討が必要であるが，我が国の $\mathrm{H}$ 形鋼を用いた SRC 長柱に関す る実験資料は十分であるとはいえず 6-11)，しかもコンクリートの劣 化性状の影響が顕著に表れる, 弱軸まわり座屈を対象としたものは 数例にすぎない $7,8,11)$.

著者は先に, 任意形状の鉄骨を持つ SRC 梁一柱の $N-M$ 相関曲線 を求める手法を示した ${ }^{12}$ ). この解析では $N-M$ 相関曲線を求めるこ とに主眼をおいているので, 偏心圧縮を受ける柱の細長比と耐力の 関係（column-curve）を求めるには適していない．本報告は文献 12) と同じ基礎方程式から出発して, 偏心圧縮 SRC 長柱のカラムカーブ を求める手法を提示し, 精密な数值解析結果と比較検討する. また, コンクリートの劣化性状の影響が顕著に表れる, 弱軸まわり座屈を 対象とした SRC 長柱の座屈実験を行い, 解析結果と比較検討する。

\section{2 偏心圧縮力を受ける SRC 長柱の耐力}

ここでは，文献 12)の基礎方程式より SRC 長柱のカラムカーブを 求める手法を提示する.

\section{1 仮定}

1) 両端に等しい偏心量 $e$ の偏心圧縮を受ける材長 $L$ の単純梁を解析対 象とし（図 1），部材は長方形断面およびサンドイッチ断面を組み合 わせた鉄骨と長方形コンクリート要素からなる（図2）.

2) 部材中央での曲率 $\kappa_{c}$ とたわみ $v_{c}$ の間には次式

$$
v_{c}=R\left(\frac{L}{\pi}\right)^{2} \kappa_{c}
$$

が成立する. 一般に，係数 $R(N)$ は軸力 $N$ の関数と見なせる.

3) 平面保持仮定が成立し，中央断面での軸ひずみ分布は， $y$ : 図心 軸からの距離, $\varepsilon_{c}$ : 図心軸ひずみ, $\kappa_{c}$ : 曲率によって表される.

$$
\varepsilon(y)=\varepsilon_{c}+\kappa_{c} y
$$

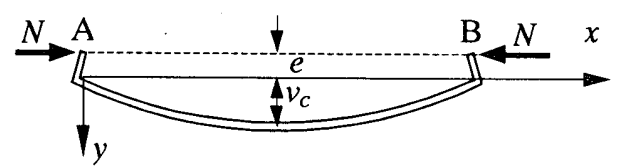

図 1 等偏心圧縮柱 
4) 材料非線形を扱うが; 塑性域でのひずみの反転による弾性除荷は考 慮しない.したがって中央断面での応力分布は図心軸ひずみおよび 曲率 $\varepsilon_{c}, \kappa_{c}$ によって一義的に定まる.

\section{2 構成則と停留条件}

中央断面での断面力 $\left(N, M_{c}\right)$ と一般化ひずみ $\left(\varepsilon_{c}, \kappa_{c}\right)$ の関倸は,

$$
\begin{aligned}
& N\left(\varepsilon_{c}, \kappa_{c}\right)=\int_{A} \sigma\left(\varepsilon_{c}+y \kappa_{c}\right) d A \\
& M_{c}\left(\varepsilon_{c}, \kappa_{c}\right)=\int_{A} y \sigma\left(\varepsilon_{c}+y \kappa_{c}\right) d A
\end{aligned}
$$

部材長の $1 / 2$ の自由体の釣り合いより

$$
M_{c}=N\left(e+v_{c}\right)=N\left\{e+R(L / \pi)^{2} \kappa_{c}\right\}
$$

また, 最大荷重時には軸力増分が 0 となる条件（停留条件）より 12 ;

$$
\overline{E K}-N R\left(\frac{L}{\pi}\right)^{2}=0
$$

ここに,

$$
\begin{gathered}
\overline{E K}\left(\varepsilon_{c}, \kappa_{c}\right) \equiv \bar{I}-\bar{S}^{2} / \bar{A} \\
\bar{A}=\int E_{t} d A, \quad \bar{S}=\int y E_{t} d A, \quad \bar{I}=\int y^{2} E_{t} d A
\end{gathered}
$$

は中央断面での接線弾性係数 $E_{t}$ の積分値より計算される.

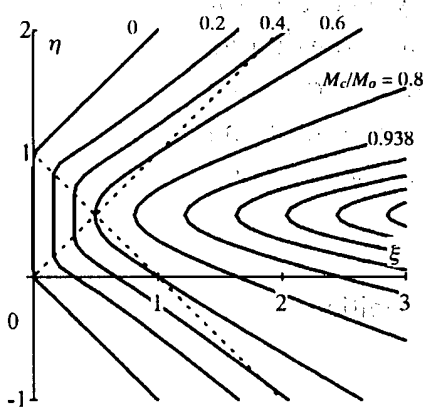

(a) $M_{C} / M_{o}-(\xi, \eta)$ 曲面

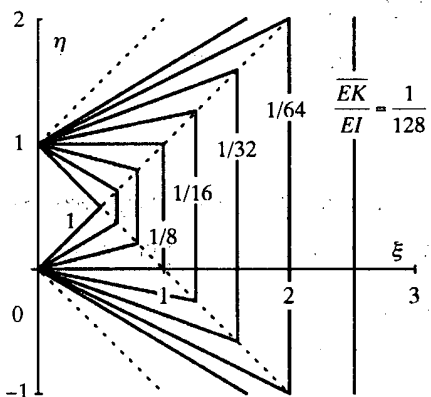

(b) $\overline{E K} /(E I)-(\xi \eta)$ 曲面

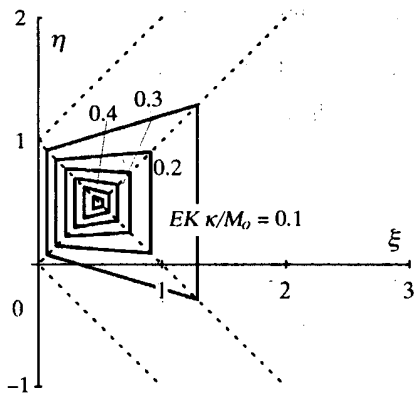

(c) $\overline{E K} \kappa / M_{0}-(\xi \eta)$ 曲面

図 4 完全弹塑性無筋コンクリート梁一柱の $F, G$ 曲面

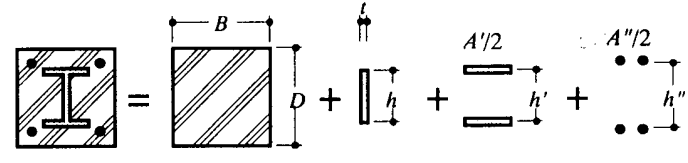

図 2 SRC 部材の断面構成

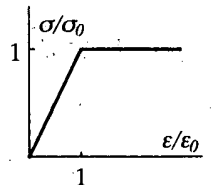

(a) Concrete

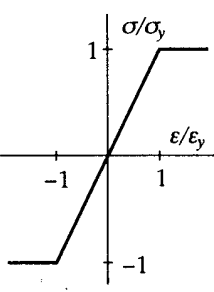

(b) Steel Elastic-plastic

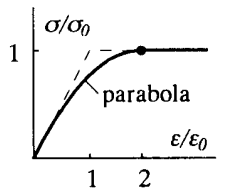

(c) Concrete

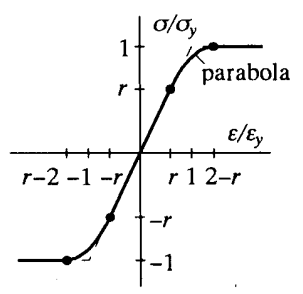

(d) Steel Parabola type
図 3 材料の構成則

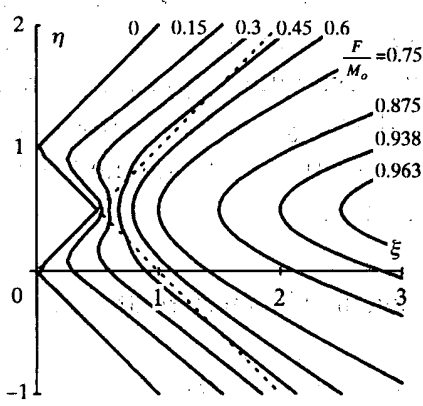

(d) $F-(\xi, \eta)$ 曲面

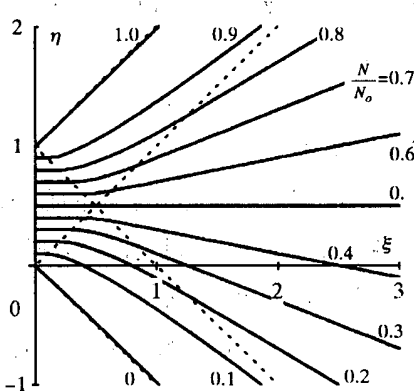

(e) $N / N_{O}-(\xi, \eta)$ 曲面

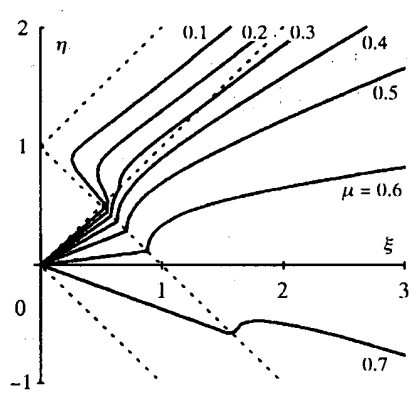

(f) 式 8(a)の解

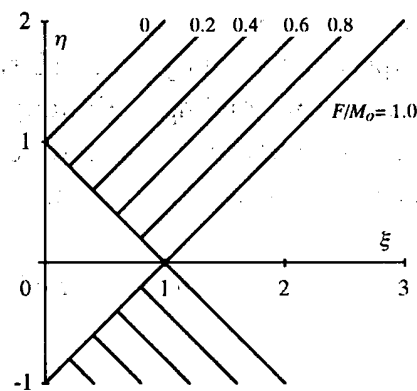

(a) $F-(\xi \eta)$ 曲面

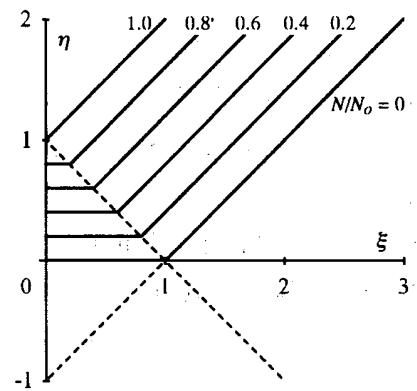

(b) $N / N_{o}-(\xi \eta)$ 曲面

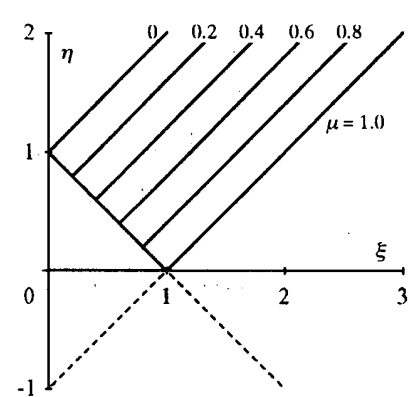

(c) 式 8(a)の解

図 5 完全弾塑性サンドイッチ 図 $6 \mathrm{SRC}$ 梁一柱の $F, G$ 曲面 鉄骨梁一柱の $F, G$ 曲面

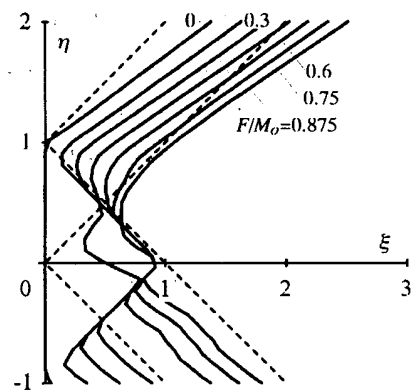

(a) $F-(\xi \eta)$ 曲面

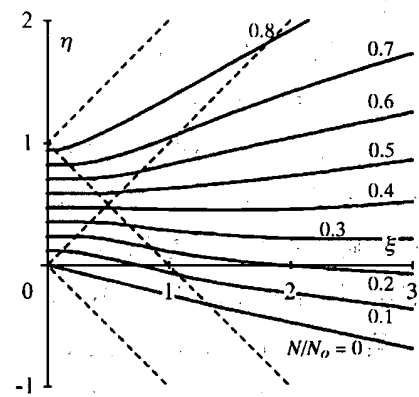

(b) $N / N_{o}-(\xi, \eta)$ 曲面

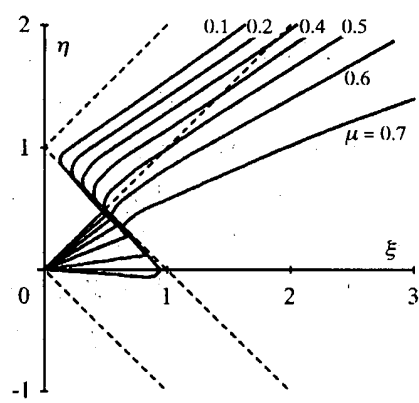

(c) 式 8(a)の解

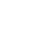




\section{3 支配方程式}

式(5), (6)より $N R(L / \pi)^{2}$ を消去すれば次式を得る.

$$
\begin{aligned}
F\left(\varepsilon_{c}, \kappa_{c}\right) & =G\left(\varepsilon_{c}, \kappa_{c}\right) \\
F\left(\varepsilon_{c}, \kappa_{c}\right) & \equiv M_{c}\left(\varepsilon_{c}, \kappa_{c}\right)-\overline{E K}\left(\varepsilon_{c}, \kappa_{c}\right) \cdot \kappa_{c} \\
G\left(\varepsilon_{c}, \kappa_{c}\right) & \equiv N\left(\varepsilon_{c}, \kappa_{c}\right) \cdot e
\end{aligned}
$$

\section{4 解析手順}

式(8a)を満たす一連の $\varepsilon_{c}, \kappa_{c}$ の組み合わせを求める作業は, $\varepsilon_{c}-\kappa_{c}$ 平面上の 2 曲面 $F\left(\varepsilon_{c}, \kappa_{c}\right)$ および $G\left(\varepsilon_{c}, \kappa_{c}\right)$ の交線の $\varepsilon_{c}, \kappa_{c}$ 座標を求め ることに帰着し, 得られた解より Euler 荷重

$$
N_{E}=\frac{E I \kappa_{c}}{M_{c}\left(\varepsilon_{c}, \kappa_{c}\right) / N\left(\varepsilon_{c}, \kappa_{c}\right)-e}
$$

と偏心圧縮耐力 $N\left(\varepsilon_{c}, \kappa_{c}\right)$ の関係を得る. また, 偏心量を 0 に近づけ れば中心圧縮柱の接線係数理論解に収斂する.

式(3),(4),(7)で定義される $N_{c}\left(\varepsilon_{c}, \kappa_{c}\right), M_{c}\left(\varepsilon_{c}, \kappa_{c}\right), \overline{E K}\left(\varepsilon_{c}, \kappa_{c}\right)$ は 材料の構成則が完全弾塑性型であれば解析的な表現が可能であり 12), 数値計算によるのであれば任意の構成則を適用することができる

\section{$2.5 F, G$ 曲面の特性}

図 3(a)の完全弾塑性型構成則に従う長方形断面無筋コンクリート 梁一柱を例に取れば, その $M_{c}$ 曲面, $\overline{E K}$ 曲面, $\overline{E K} \cdot \kappa_{c}$ 曲面, $N$ 曲 面の等高線は図 4(a) (c), (e)のように表される. 横軸 $\xi=\kappa_{c} D /\left(2 \varepsilon_{o}\right)$ は曲率の無次元量, 縦軸 $\eta=\varepsilon_{c} / \varepsilon_{o}$ は図心軸ひずみと降伏ひずみの 比, 基準曲げ強度 $M_{o}=F_{c} B D^{2} / 8$ は中立軸が断面中心を通るときの 全塑性モーメント, $B, D$ は部材の幅とせい, $F_{c}$ はコンクリート強度, $E I$ は曲げ剛性, $N_{o}$ は降伏軸力である. 式 $(8 \mathrm{~b})$ で定義される $F$ 曲面は 図 4(a), (c)の差として同図(d)のように表され, $N$ 曲面と相似形の $G$ 曲面との交線が求める解となる（同図(f)）. 図中の $\mu=N_{o} e / M_{o}$ は
無次元偏心量である. 図 3(b)の完全弾塑性構成則に従うサンドイッ チ断面鉄骨梁一柱に対する同様の考察を図 5 に示す.

図 6 は，図3(a), (b)の構成則に従う図 7 の断面形の SRC 長柱の $F$, $N$ 曲面および式 8(a)の解を示す. 変数の無次元化に当たっては, 降 伏ひずみおよび部材せいはコンクリート要素の值を用い, $N_{o}$ は各構 成要素の降伏軸力の和, $M_{o}$ は基準曲げ強さの和とした.

\section{3 偏心圧縮力を受ける SRC 長柱の実験 \\ 3.1 実験概要}

試験体の概要を表 1 , 図 7 に示す. 4 種類の材長と中心圧縮および 2 種類の偏心圧縮の組合せで計 12 体の圧縮実験を行った. 本実験の 一部は文献 13)に報告した. 表 1 中の基準曲げ強度 $M_{o}$ は中立軸が断 面中心を通るときの全塑性モーメントであり， $\Lambda=\sqrt{N_{o} / N_{E}}$ は無 次元化細長比である.

鉄骨は板厚 $6 \mathrm{~mm}$ の鋼板を溶接して製作し，焼鈍を行った．主筋 およびフープはコンクリートの充填性を最優先して $9 \mathrm{~mm}, 3 \mathrm{~mm}$ の丸 鋼を用いた，座屈実験で部材に生じるせん断力は小さいので, 鋼材 とコンクリートの付着性状の影響は小さいと考えられる．鉄骨のフ ランジおよびウェブより採取した引張試験片，および鉄筋の材料試 験結果を表 2, 図 8 に示す．主筋の応力ーひずみ関係は標準的な軟 鋼の性状を示している. フランジとウェブの鋼材は異なる素材より 採取したので降伏応力は異なるが，いずれも降伏比が大きく伸び率 も小さい．フープ筋は細径でかつ降伏棚が発現するように特注した 材料で，伸び率は十分であるが，降伏比は大きい.

長柱の場合, 座屈に伴うせん断力はわずかであり, フープはコン クリートの剥落防止効果が卓越する. しかし, 最大耐力時の軸ひず みはコンファイン効果が発揮されるほど大きくないので, 主筋やフ 一プの材料特性が実験結果に及ぼす影響は小さいと考えられる.
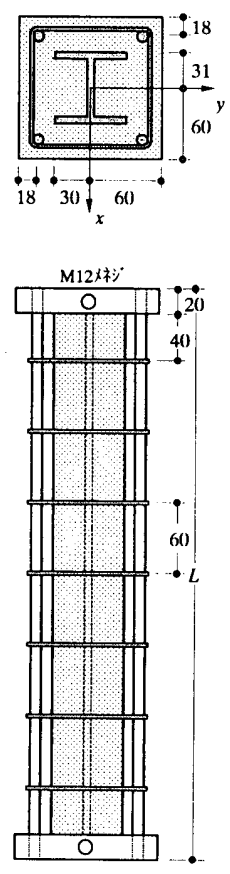

図 7 試験体

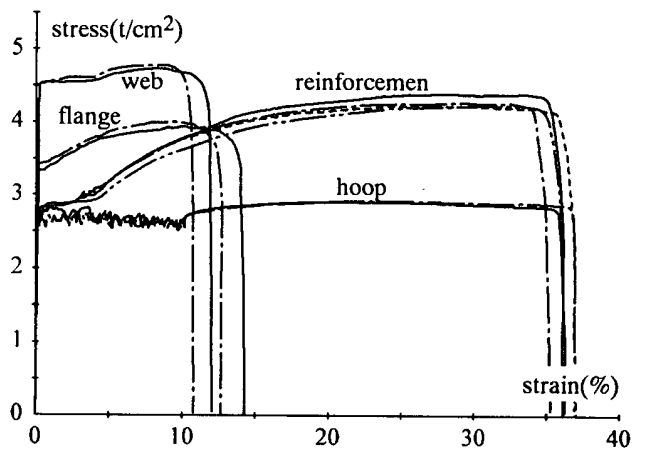

図 8 鋼材の引張試験

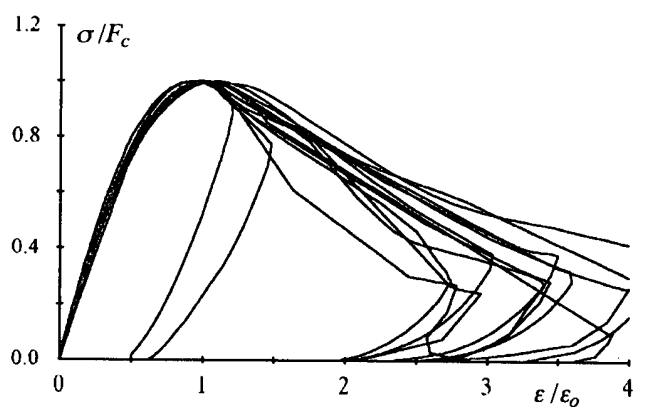

図 9 コンクリートの圧縮試験
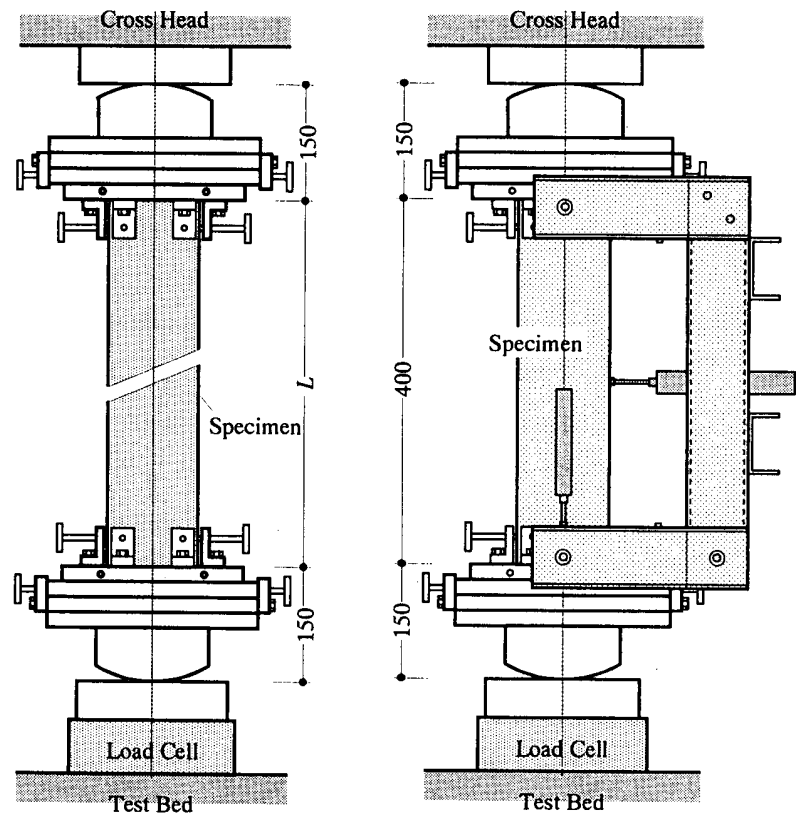

図 10 載荷システムと測定フレーム $(L / D=4)$ 
表 1 試験体概要

\begin{tabular}{|c|c|c|c|c|c|c|c|c|c|c|c|c|}
\hline 試験体 & $\mathrm{X} 040$ & $\mathrm{X} 041$ & $\mathrm{X} 042$ & $\mathrm{X} 080$ & $\mathrm{X} 081$ & $\mathrm{X} 082$ & $\mathrm{X} 120$ & $\mathrm{X} 121$ & $\mathrm{X} 122$ & $\mathrm{X} 180$ & $\mathrm{X} 181$ & $\mathrm{X} 182$ \\
\hline コンクリート強度 $F_{c}\left(\mathrm{t} / \mathrm{cm}^{2}\right)$ & 0.433 & 0.440 & 0.440 & 0.474 & 0.443 & 0.471 & 0.487 & 0.455 & 0.493 & 0.430 & 0.457 & 0.471 \\
\hline 材長 $L(\mathrm{~cm})$ & 48 & 48 & 48 & 96 & 96 & 96 & 144 & 144 & 144 & 216 & 216 & 216 \\
\hline 偏心量 $e(\mathrm{~cm})$ & 0 & 1.3 & 2.35 & 0 & 1.3 & 2.8 & 0 & 1.30 & 2.55 & 0 & 1.30 & 2.50 \\
\hline 降伏軸力 $N_{O}(\mathrm{t})$ & 104.5 & 105.8 & 106.6 & 112.2 & 106.7 & 109.9 & 111.7 & 107.5 & 112.6 & 107.1 & 107.5 & 109.7 \\
\hline 基準曲げ強度 $M_{O}(\mathrm{tcm})$ & 159.6 & 163.0 & 164.7 & 175.6 & 164.7 & 168.6 & 171.4 & 164.4 & 172.8 & 168.4 & 164.6 & 168.0 \\
\hline 弾性座屈荷重 $N_{E}(\mathrm{t})$ & 2935 & 3018 & 3057 & 823 & 766 & 763 & 341 & 332 & 343 & 161 & 147 & 150 \\
\hline 無次元細長比 $\Lambda$ & 0.189 & 0.187 & 0.187 & 0.369 & 0.373 & 0.380 & 0.573 & 0.569 & 0.573 & 0.815 & 0.855 & 0.854 \\
\hline 実験耐力 $P_{x}(t)$ & 109.2 & 74.6 & 52.7 & 107.9 & 66.7 & 46.1 & 97.2 & 58.2 & 37.0 & 81.5 & 33.6 & 24.0 \\
\hline 偏心率 $\mu=N_{O} e / M_{O}$ & 0 & 0.844 & 1.520 & 0 & 0.842 & 1.825 & 0 & 0.850 & 1.661 & 0 & 0.849 & 1.633 \\
\hline$n=P_{X} / N_{O}$ & 1.045 & 0.705 & 0.494 & 0.962 & 0.625 & 0.419 & 0.870 & 0.541 & 0.330 & 0.762 & 0.312 & 0.218 \\
\hline$m=P_{X} e / M_{O}$ & 0 & 0.595 & 0.752 & 0 & 0.526 & 0.765 & 0 & 0.460 & 0.547 & 0 & 0.265 & 0.356 \\
\hline
\end{tabular}

表 2 鋼材の引張試験結果

\begin{tabular}{lrlll}
\hline & 7ラシジ & ウエプ & 主筋 & $7-7^{\circ}$ \\
\hline 降伏応力 $\left(\mathrm{t} / \mathrm{cm}^{2}\right)$ & 3.47 & 4.63 & 2.85 & 2.57 \\
引張強度 $\left(\mathrm{t} / \mathrm{cm}^{2}\right)$ & 3.97 & 4.76 & 4.23 & 3.07 \\
伸び率 $(\%)$ & 13.1 & 11.1 & 35.5 & 36.7 \\
\hline
\end{tabular}

表 3 コンクリートの調合 $\left(1 \mathrm{~m}^{3}\right.$ 当たり $)$

水セメ比細骨材率 水 セxン 砂砂利 ポリ゙リス $\mathrm{AE}$ 助剤

\begin{tabular}{llllllll}
$64 \%$ & $50.2 \% \quad 215 \mathrm{~kg} \quad 334 \mathrm{~kg} \quad 817 \mathrm{~kg} \quad 844 \mathrm{~kg}$ & $3.35 \ell$ & $0.35 \ell$ \\
\hline
\end{tabular}

表 4 コンクリート材料の概要

\begin{tabular}{|c|c|}
\hline セメント & 普通ポルトランドセメント, 比重 : 3.16 \\
\hline 細骨材 & 京都府城陽産山砂, 比重 : 2.56 , 吸水率 : 2.0 , 粗粒率 : 2.80 \\
\hline 粗骨材 & 大阪府高柣産採石, 比重 : 2.67 , 吸水率 : 0.7 , 実績率 : 56 , 最大粒径 : 10 \\
\hline $\mathrm{AE}$ 減水刘 & ポソリス N070, 比重 : 1.07 , 原液換算使用率 : $\mathrm{C} \times 0.25 \%$ \\
\hline
\end{tabular}

コンクリートの調合は表 3 を基準とし, 細骨材の表面水量に応じ て水と細骨材量を補正した. コンクリート材料の概要を表 4 に示す. コンクリート打設は横打ちとし, 屋外で打設後 2〜3 日間シートを被 せ, 脱型した後は 5〜9 週間標準水中養生し, その後空中養生とした. 実験時の材令は 287 332 日であり, 平均強度は $455 \mathrm{~kg} / \mathrm{cm}^{2}$, 標準偏 差は $17 \mathrm{~kg} / \mathrm{cm}^{2}$ であった. 図 9 にコンクリートの王縮強度試験結果 の例を示す. 縦軸は最大強度 $F_{c}\left(\mathrm{t} / \mathrm{cm}^{2}\right)$ で, 横軸は最大応力時のひず み $\varepsilon_{0}$ で無次元化されている. $\varepsilon_{0}$ は実測值ではな $\varepsilon_{0}=2 F_{c} / E_{c}$ で評 価し, コンクリートの初期弾性係数は $E_{c}=210 \sqrt{5 F_{c}}\left(\mathrm{t} / \mathrm{cm}^{2}\right)$ とした.

載荷および測定システムの概要を図 10 に示す．試験体をかまぼこ 球座を介して長柱試験機に設置し, 約 $30 \mathrm{t}$ の圧縮力をかけた状態で 部材中央の横たわみが最小となるように上下端の材端移動装置を調 整し，その状態を中心圧縮の状態とした．偏心圧縮実験では中心圧 縮の状態から材端移動装置を操作して所定の偏心量を与えた.

部材端を支点とする測定フレームに設置した 2 個の $1 \mathrm{~cm}$ ストロー クの変位計により材軸方向変位を, $5 \mathrm{~cm}$ ストロークもしくは $10 \mathrm{~cm}$ ストロークの変位計により部材中央の横たわみを測定した.

\section{2 実験結果と考察}

\section{1）最大荷重および荷重一横たわみ関係}

実験で得られた最大荷重を表 1 中に「実験耐力」として示す. また, 実験で得られた荷重と中央点横たわみの関係を図 11 中に, 荷重と中 央点曲げモーメント関係を図 12 中に実線で示す. 図中の破線は, 図 3(c),(d)のパラボラ型構成法則を用いた図 13 の解析モデルによる数值
解析結果である. 図 3(d)中の比例限度 $r$ は $r=0.6$ とした. 図 11 の 両軸はそれぞれ部材の降伏軸力 $N_{o}$ および材長 $L$ で無次元化されて おり, $L / D=8,12$ の試験体では, 最大荷重に到るまでの経過は実験 值と解析結果の対応は良好であるが, 最大耐力以降の経緯は実験值 が解析結果を相当下回る.これは，解析においてコンクリートの劣 化性状を考慮していないためと考えられる. $L / D=4$ の場合, コン クリートの圧壊・少化が早期に発生し, 解析曲線が最大耐力に到る 前に実験値の耐力低下が開始し，その後の耐力低下も解析結果に比 べて著しい， $L / D=18$ の偏心圧縮柱では, 実験で得られた耐力は数 值解析結果を下回る.これらの試験体では実験值の初期剛性も数值 解析結果に比べて低いので偏心量の制御を誤った可能性がある. な お，解析にあたっては塑性域でのひずみの反転に伴う弾性除荷の影 響についても検討したが, 有意な影響は認められなかった.

2) 荷重一中央点曲げモーメント関係

実験で得られた軸力と中央点曲げモーメントの関係を図 12 中に実 線で示す．横軸は 2.1 節で定義された基準曲げ強度 $M_{o}$ で無次元化さ れており, 破線で示された $N-M$ 曲線は差分法による数值解析結果, 細点線の相関曲線は累加強度理論解, 1 点鎖線は文献 12)の手法で得 られた長柱の相関曲線, ○印は実験で得られた最大耐力時の軸力と 材端モーメントの関係を示す. $L / D=8,12$ の偏心圧縮柱では, 最 大耐力に至るまでは数值解析結果は実験值と良く対応している. 数 值解析ではコンクリートの劣化性状を考虑していないので最大耐力 以降の解析結果が累加強度相関曲線に渐近していくのに対して, 実 験値は最大耐力に達した直後から急激に相関曲線の内側に進み, 中 


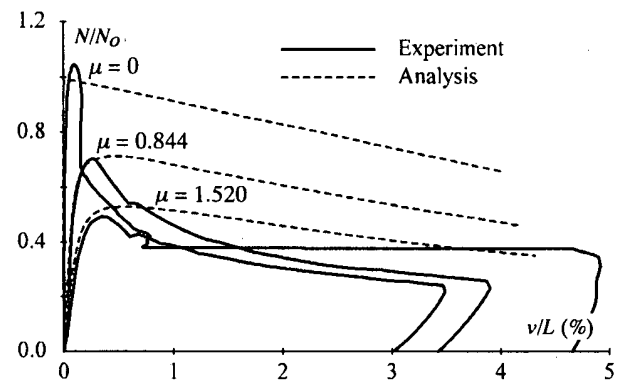

(a) $L / D=4 \quad(\Lambda=0.19)$

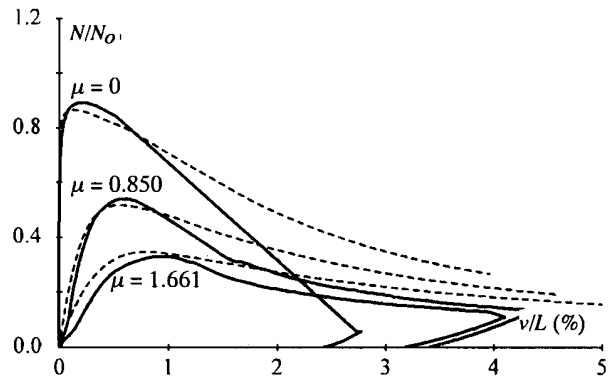

(c) $L / D=12 \quad(\Lambda=0.57)$

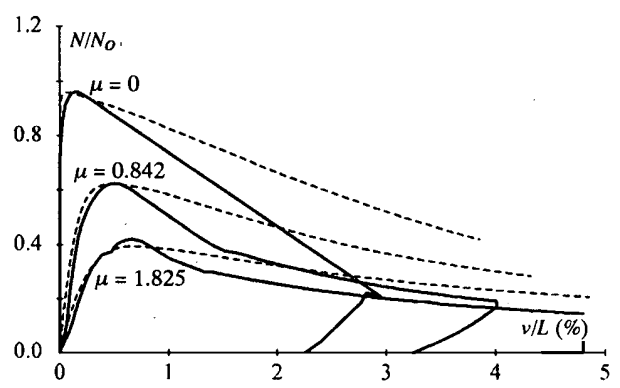

(b) $L / D=8 \quad(\Lambda=0.38)$

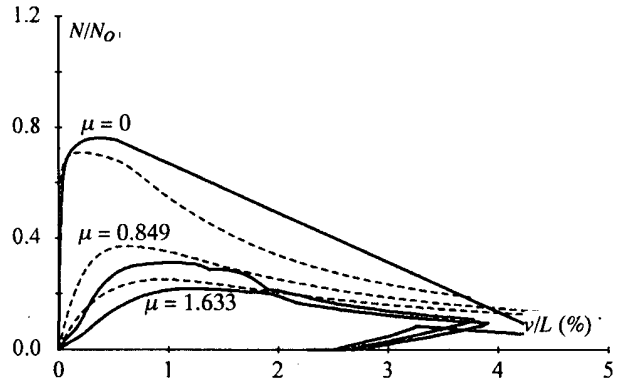

(d) $L / D=18 \quad(\Lambda=0.84)$

図 11 荷重一中央点横たわみ関係

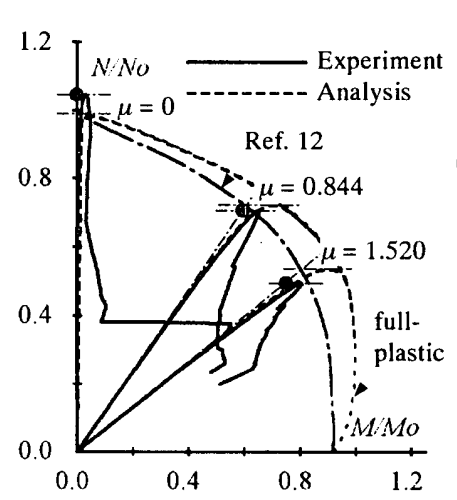

(a) $L / D=4(\Lambda=0.19)$

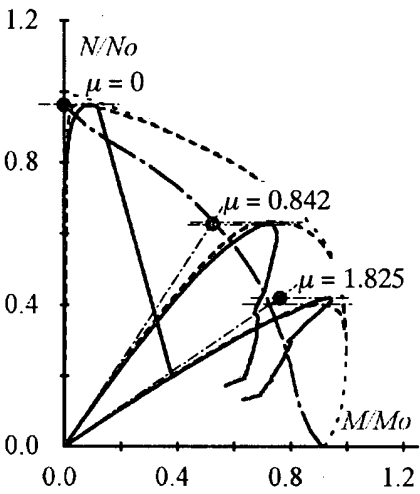

(b) $L / D=8(\Lambda=0.38)$

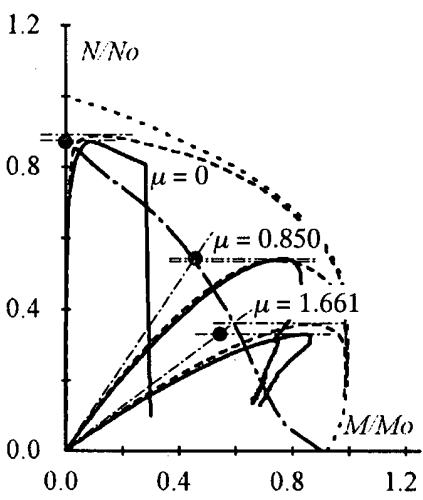

(c) $L / D=12(\Lambda=0.57)$

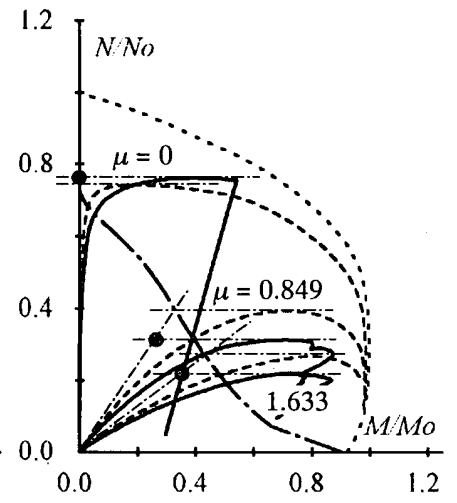

(d) $L / D=18(\Lambda=0.84)$

図 12 荷重一中央断面曲げモーメント関係

央断面の応力状態は全塑性状態に達し得ない. コンクリートの最外 縁が鋼材で保護されているコンクリート充填鋼管長柱と, 通常の SRC 長柱との相違はこの点にある. $L / D=4$ の偏心圧縮柱ではコンクリ 一トの圧壊・劣化が早期に生じるため解析結果が最大耐力に至る前 に実験值は最大值に達し, $N-M$ 曲線は急激に相関曲線の内側に進む. 最大耐力時の軸力と材端モーメントの関係を示すの印は相関曲線の 内側に位置する. $L / D=18$ の偏心圧縮柱では $N-M$ 曲線の実験值は 早い段階から数值解析結果を下回り, 最大耐力も相当低い.

\section{3) $N-M$ 相関曲線}

最大荷重時の軸力と材端モーメントの関係を図 14 に示す. 図中の ○印は実験值, 実線は文献 12)手法による長柱の相関曲線であり, 式 (1)中の $R$ は $R=1.05$ とした. コンクリートおよび鋼材の構成法則は パラボラ形を用い, 鋼材の比例限度は $r=0.6$ とした. $L / D=18$ の 場合を除いて解析結果と実験值の対応は良好である.

4) カラムカーブ

中心圧縮柱に対する接線係数理論解および偏心圧縮柱に対する本 解析と実験結果との比較を図 15 に示す. 縦軸 $N / N_{o}$ は最大圧縮力と
降伏軸力の比, 横軸 $\Lambda=\sqrt{N_{o} / N_{E}}$ は無次元細長比である. 図中の $\mu=N_{o} e / M_{o}$ は無次元偏心量であり, 実線, 1 点鎖線, 破線は図 3 に示す構成材料の構成法則を表 5 のように組み合わせた場合の解で ある. パラボラ型構成則の鋼材の比例限度は $r=0.6$ とした.

偏心圧縮柱の解析結果は構成法則の組み合わせにはそれほど影響 表 5 構成則の組み合わせ

\begin{tabular}{c|cc}
\hline & コンクリート & 鋼材 \\
\hline 実線 : 解析 1 & 完全弾塑性 & 完全弾塑性 \\
鎖線 : 解析 2 & パラボラ型 & 完全弾塑性 \\
破線 : 解析 3 & パラボラ型 & パラボラ型 \\
\hline
\end{tabular}

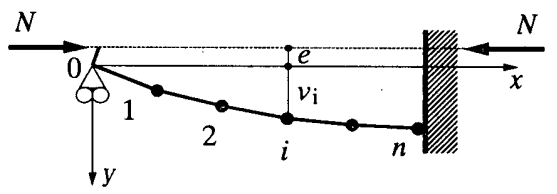

図 13 差分法による解析モデル 


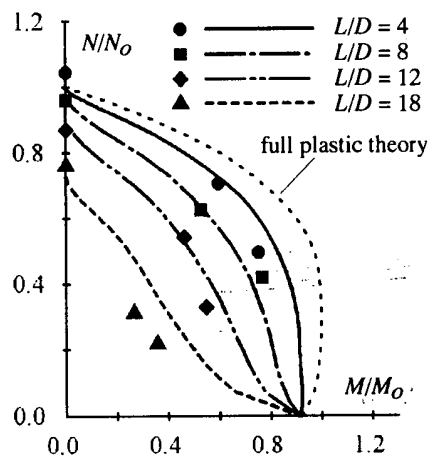

図 $14 N-M$ 相関曲線

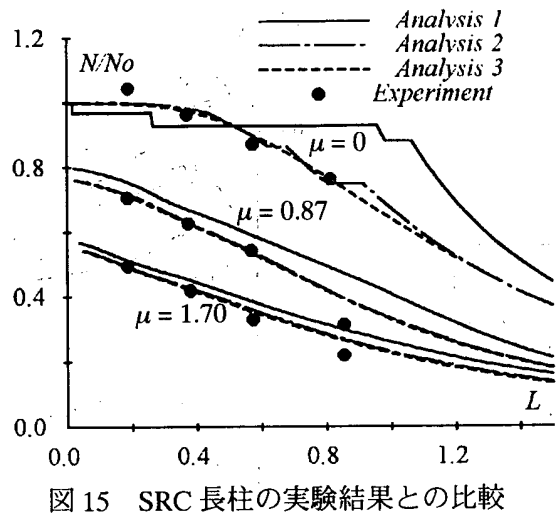

図 15 SRC 長柱の実験結果との比較

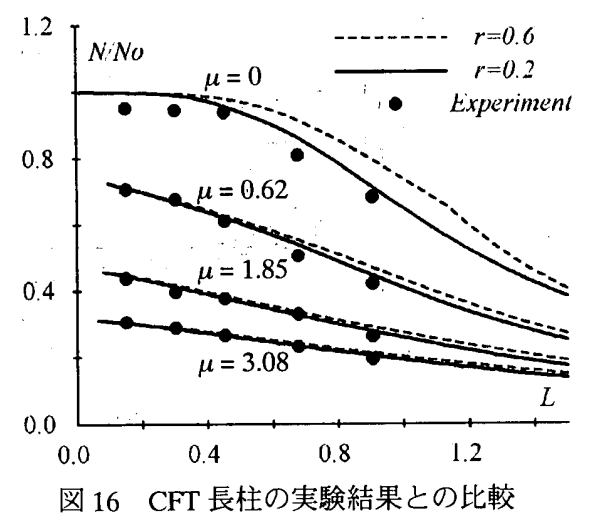

図 16 CFT 長柱の実験結果との比較
されず, 特に解析 2 と解析 3 はほとんど差がない. $L / D=18, \mu=0.87$ の場合を除き，実験值は解析結果と良好な対応を示している.

しかし, 中心圧縮柱の接線係数理論解は構成法則の組み合わせに 大きく依存し, 完全弾塑性型の材料を含む場合はカラムカーブの途 中に何個所かの踊り場を生じる.コシクリートと鋼材の両方を完全 弾塑性型とした解析 1 は実状にほど遠いが, 両材料ともパラボラ型 とした解析 3 は滑らかなカラムカーブを描き, 実験値との対応もよ い.コンクリートのみをパラボラ型とした解析 2 は数個所に小さな 踊り場を生じるが解析 3 と有意な差はない.

図 16 は松井他によるコンクリート充填角形鋼管の圧縮実験と本解 析（解析 3）との比較を示す. 鋼材の比例限度は $r=0.6$ および $r=0.2$ とした. 冷間成形鋼管では加立硬化の影響で見かけの比例限度が低 下するため, 実験値と解析の対応は $r=0.2$ の場合に良好である.

\section{4 結論}

偏心庄縮を受ける SRC 長柱の圧縮耐力に関する理論解析および実 験を行った結果以下の結論を得た.

1) 任意の構成則と任意断面鉄骨を持つ SRC 長柱が両端に等しい偏心量 の偏心圧縮を受ける場合の, 最大耐力の一般解を導いた.

2) 完全弾塑性型の構成則を仮定すれば支配方程式は解析的に表現され る. 支配方程式を数值解析により評価するのであれば, 任意の構成 則を用いることができる.

3) 偏心量を 0 に近づければ中心圧縮柱の接線係数理論解に収斂する.

4) 実験で得られた荷重一横たわみ関係は, 最大耐力に達する直前まで はコンクリートの劣化を考慮しない数值解析結果と良好な対応を示 したが, 最大耐力に達してからはコンクリートの劣化性状が卓越し, 数值解析結果は危険側の誤差を与える.

5) 最大耐力に及ぼすコンクリートの劣化特性の影響はわずかである.

6) SRC 長柱の圧縮耐力はパラボラ型のコンクリードの構成則を用いる ことにより精度よく予測し得る.

7) 中心压縮柱に対する接線係数理論解および偏心圧縮柱に対する本解 析結果は実験值と良好な対応を示した.

\section{謝辞}

球座装置を貸与して頂いた神戸大学工学部 大谷恭弘助教授, な らびにコンクリートの打設に関して便宜を賜つたタイコーKK 藤木 英晴氏に厚く感謝します: 本研究は平成 7,8 年度文部省科学研究費 基盤研究(c)「H 形鋼を用いた SRC 長柱の弱軸回り曲げ座屈耐力に関 する実験的研究」（研究代表者 : 柴田道生）の一部として行われた.

\section{参考文献}

1) Basu, A.K : Computation of Failure Loads of Composite Columns, Proceedings, Inst. Civil Engrs., Vol.36, pp.557-578, Mar. 1967.

2) Basu, A.K. and Hill,W.F. A More Exact Computation of failure Loads of Composite Columns, Proceedings, Inst. Civil Engrs., Vol.40, pp.37-60, May 1968.

3) Roderick, J.W. and Rogers, D.F. : Load Carrying Capa-city of Simple Composite Columns, Jour. Structural Div., ASCE, Vol.95, No.ST2, pp.209-228, Feb. 1969.

4) Shakir-Khalil, HR and Zeghiche, Z. : Experimental Behavior of Concrete Filled Rolled Rectangular Hollow Section Columns, The Structural Engineer, Vol.67, No.19, pp.346-353, Oct. 1989.

5) 浅草 肇・中村 武・若林 實: 鉄骨コンクリート長柱の最大強度 ( $\mathrm{H}$ 形鋼およびヨンクリート部分の不整形による影響)，構造工学論文集，日 本建築学会, Vol.34B, pp.201-209, 1988:3.

6) 若林 實, 南 宏一; 柴田道生, 忠田圭史 : 中心圧縮力を受ける鉄骨コ ンクリート・鉄筋コンクリート長柱の弾塑性挙動に関する奏験的研究, 日本建築学会大会学術講演梗概集（構造系），pp.1207-1208, 1975.10.

7) 松井千秋, 森野捷輔 他：2 軸偏心圧縮を受ける SRC 長柱の弾塑性性状 に関する研究（その1），日本建築学会大会学術講演梗概集（構造系）, pp.1627-1628; 1979.09.

松井千秋, 森野捷輔 他: 2 軸偏心圧縮を受ける SRC 長柱の弾塑性性状 に関する研究（その2），日本建築学会大会学術講演梗概集（構造系）, pp.1887-1888, 1980.09.

8) 鈴木敏郎, 滝口克己 他 : 細長い SRC 部材の偏心圧縮, 引張実験, 日本 建築学会大会学術講演梗概集（構造系），pp.2475-2476，1983.10.

9) 鈴木敏郎, 滝口克己 他 : SRC 柱の中心及び偏心圧縮実験（その1 実 験計画），(その 2 実験結果），日本建築学会大会学術講演梗概集（構 造系), pp.2741-2744, 1984.10 .

10)浅草 肇・中村 武・若林、實：一定軸方向力と対称曲げ・非対称曲げ を受ける鉄骨鉄筋コンクリート長柱の弾塑性挙動, 構造工学論文集, 日 本建築学会, Vol.37B, pp.437-446, 1991.03 .

11)松井千秋・津田恵吾・尾崎 功・石橋靖夫：コンクリート充填鋼管長柱 の耐力, 日本建築学会構造系論文集, No.494, pp.137-144, 1997.04.

12)柴田道生 : 任意形状の鉄骨を持つ SRC 長柱の $N-M$ 相関曲線, 日本建築 学会構造系論文集, No.493, pp.139-146, 1997.03:

13)柴田道生 : H 形鋼を用いた SRC 長柱の弱軸まわり曲げ座届耐力に関する 実験的研究, 1997 年度コンクリート工学年次論文報告集, pp.1485-1490, 1997.06

(1997年11月 7 日原稿受理, 1998年 7 月 3 日採用決定) 